\title{
Kırsal Alandaki Yaşlıların Ölüm Yeri ve Ölüm Deneyimi Arasındaki İlişki
}

The Correlation Between the Place of Death and Death Experience of the

\author{
Elderly in Rural Areas
}

\section{Serdar Nerse}

\section{Öz}

Çalışmada, çoğunlukla sağlık, din, hukuk gibi alanlarda yer bulan ölüm konusu, sosyolojik bir perspektifle değerlendirilmiştir. Bu bağlamda, yaşlıların ölüm deneyimleri (iyi ve mutlu ölüm) esas alınarak ölüm yeriyle ilişkisinin incelenmesi amaçlanmıştır. Ölüm yeriyle iyi / mutlu ölüm arasındaki ilişkiyi tespit etmek için 65 yaş ve üstü bireyler demografik, sosyo-ekonomik, sağlık özelliklerine göre tespit edilmiştir. Çalışmada ölüm olayı esas alındığından, amacımıza uygun çok aşamalı bir örneklemle belirlenen toplam 102 katılımcının yakını veya bakıcısına anket uygulanmıştır. Katılımcıların belirlenmesinde temel özelliklerin yanı sıra ) farklı kırsal kesimlerden hastalık tipine sahip olanlar ile ii) eğitimli ve yüksek gelirli yaşlılar karşılaştırılmıştır. Yaşlıların yakını ve bakıcılarının verdikleri cevaplara göre ölüme ilişkin fiziksel ve psikolojik durum gözlemlenmiştir. Çalışma sonucunda yaşlı bireylerin temel özellikleri ile sınıfsal konumlarına bağlı olarak, ölüm yeri ve ölüm modelleri arasında bir farklılaşma olduğu sonucuna ulaşılmıştır.

Anahtar Kelimeler: Ölüm yeri, iyi-mutlu ölüm, palyatif bakım, yaşlılık, kırsal alan.

Dr. Öğr. Üyesi, Batman Üniversitesi, Fen-Edebiyat Fakültesi, Sosyoloji Bölümü Öğretim Üyesi, serdarnerse@yahoo.com.tr

Bu makale iThenticate sistemi tarafından taranmıştır.

Makale Gönderim Tarihi: 9 Ekim 2020 


\begin{abstract}
In the study, the subject of death, which mostly takes place in fields such as health, religion and law, has been evaluated from a sociological perspective. In this context, it was aimed to examine the relationship between place of death and good / happy death based on the death experiences of the elderly. In order to determine the relationship between place of death and good / happy death, individuals aged 65 and over were identified according to demographic, socio-economic and health characteristics. Since the death event was taken as a basis in the study, a questionnaire was applied to the relatives or caregivers of 102 participants, who were determined with a multi-stage sample suitable for our purpose. In determining the participants, besides the basic characteristics), those from different rural areas with disease types and ii) educated and high-income elderly were compared. According to the answers given by the relatives and caregivers of the elderly, the physical and psychological condition related to death was observed. As a result of the study, it was revealed that there is a differentiation between the place of death and death models depending on the basic characteristics of the elderly people and their class locations.
\end{abstract}

Keywords: Place of death, good-happy death, palliative care,elderly, rural area. 


\section{Giriş}

Sağlık alanında çoğunlukla çalışılan ölüm, erken dönemde din bilimleri ve antropolojide, ilerleyen dönemlerde de tarih, hukuk, psikoloji ve sosyolojide inceleme konusu olmuştur. Ölüm olayının çalışma biçimi disiplinlere ve zamana göre farklılaşmalar göstermektedir. Ölümün yaygın bir şekilde çalışma konusu olması 1950'lerin sonlarına denk gelmektedir. Öncelikle Kuzey Amerika'da psikolojinin egemenliğinde disiplinler arası bir şekilde (Corr vd., 1999) alan genişletmeye başlayan ölüm olayına ilişkin çalışmalar son dönemlerde de sosyolojide yoğun bir biçimde çalışılmaya başlanmıştır. Ölüm, ölme ve yas tutmayla ilişkili araştırmalarla zenginleşen alan, yaşamın sonunun dinsel, psikolojik, antropolojik, temel sağlık sorunlarıyla popülerlik kazanmıştır. Diğer yandan, ölümün yalnızca bireylerin psikolojisiyle açıklanabilecek dar bir olay olmadığı ortadadır. Sağlık, dinsel ve kültürel boyutlarının yanı sira toplumsal etkilerinin de incelenmesi ihtiyacı bulunmaktadır. Dolayısıyla, ölüm farklı bağlamlarıyla yeni bir alan olarak çalışılmaktadır. Birleşik Krallık'ta eğitimsel boyutuyla ele alınan (Pine, 1977; 1986) ölüm olayı, Batı toplumlarında yeni bağlamlarıyla tartışılmaya başlanmıştır. Ölümle ilgili kursların ortaya çıkması ve sayılarının artması, bakım, ölüm öncesi ve sonrası diğer hizmetler konusunda hem üniversite (alandaki konuları ele alan uluslararası seminer ve konferanslar da artması) hem de üniversite dışında bu alana yönelik çabaların artması buna işarettir.

Erken dönem sosyoloji çalışmalarında ölüm ve ilişkili kavramlar din, inanç, cemaat, kimlik gibi toplumsal kurum ve olgularla ele alınmıştır. Her konu farklı yaklaşımlarla çeşitli sembolik ilişkilerle ele alınmıştır. Sosyolojide bu bağlamda erken dönem çalışmalarının da olduğu görülmektedir. Dini grupların bir araya gelme olayı ve bu grupların kolektif kimlikleri ile sembolleri (Durkheim, 2011), Püritenlerin ölüm sonrası yaşamı ile kapitalizm ilişkisi (Weber, 2011) erken dönem çalışmalarındandır. Ölüm olayı, 1960’lar sonrasında kuramsal bağlamda erken dönem çalışmalarının örneklenmesiyle parçalı (Faunce ve Robert, 1958), Durkheimvari analizler (Warner, 1959), birkaç yıl sonra da klasik etnometodolojik çalışmalar (Sudnow, 1967) ve yeni teoriler geliştirme (Glaser ve 
Strauss, 1965) şeklinde yer bulmuştur. Ölüm konusunu inceleyen sosyologlar, öncelikle bu kavrama yönelik teori ve yöntemler geliştirmiş veya kavramla ilişkili konuları ana hatlarıyla açıklamaya çalışmışlardır. Son dönemlerde, ölüm konusuyla ilişkili bir şekilde fakirlik, yerinden edilmişlik ve yaşlılık neticesinde ölümün farklı görünümleri, tabular ve sekestrasyon, ölüm ve medya, kolektif bellek ve Holokost'un entegrasyonu, çağdaş geçit törenlerinin kuramsallaştırılması (Walter, 2008) gibi farklı konular çalışılmaktadır. Ölümün farklılaşması; ölüden sonra geride kalanlar ve ölünün bıraktıkları, ölüm öncesinde ve sonrasındaki eşitsizlikler, yas günleri ile anma ritüellerinde ölümle doğrudan karşılaşanlarla belirginleşmektedir. Diğer yandan ölüm öncesi bakım ve sonrasındaki duruma, anlamına ve örgütlenmesine yönelik odaklanma ihtiyacıyla ilişkili çalışmalar ise eksiktir. Ölümün yarattığı etki, ölen kişinin sosyal statüsüne ve cenazeye katılım görünürlüğünü ve duygusallığı arttırsa da (Blauner, 1966) ölümde kırsal-kentsel alanda ölüm, zengin / fakir ölümü, sanatçının ve siyasetçinin ölümünde farklılaşmalara, eşitsizliklere ilişkin karşılaştırmalı analizlere sosyolojide çok az yer verilmiştir. Ölümle ilgili sosyolojik tartışmalar çoğunlukla genel tartışmalar şeklindedir. Ölüme ilişkin kavramlar ve kuramlar, 1970'lerde İngiltere'de başlayan tıp çevresi ve ölümün tıbbileşmesi araştırmalarının gölgesinde kalmış ve öncesindeki dinsel inançsal değerlerle ilişkili bir şekilde günümüze kadar devam etmiştir. 2010 ve sonrasında ölme, ölüm ile yas olayına ilişkin tartışmalar yeni yeni çevre/alan, eşitsizlikler, algılar ile toplumsal duygular temelinde ele alınmaktadır. Ancak bu çalışmaların neredeyse tamamı kentsel alanda yaşayanlarla ilgilidir. Kırsal alanda ölümle ilgili çalışmaların neredeyse bulunmadığını belirtmek gerekir.

Ölümlerin önemli bir bölümü, kentsel alanda palyatif bakımla ilişkili olarak ele alınmıştır. Palyatif bakım ölüm öncesinde kişinin genel durumunu iyileştirme, onu mutlu etme, acısını dindirmeye ilişkin bir hizmet olarak toplumsal bağlamda önemli bir süreç olarak git gide önem kazanmıştır. Dünya Sağlık Örgütü (WHO), palyatif bakımı; "yaşamı tehdit eden hastalıklarla ilgili sorunlarla karşılaşan hastaların ve ailelerinin yaşam kalitesini artıran bir 
yaklaşım" (WHO, 2004) olarak tanımlamaktadır. Elbette, gelişmiş toplumlarda olduğu üzere yaşam kalitesi bir yönüyle insan bakımiyla ilişkilidir. Yaşam sonuna doğru, özellikle hasta yaşlılarda palyatif/hafifletici bakım ile iyi / mutlu ölüm arasında ilişki olduğu reddedilmez bir gerçek olarak oturmuştur. Ancak kentsel alandaki kurumsallaşmış bakımla ilişkili ölümü, bütünüyle mutlu ölüm olarak açıklamak da yanlış olur. Literatürde de geçtiği üzere, insanlar çoğunlukla evde ölmeyi tercih ettiğinden, palyatif bakımda amaç insanların tercih ettikleri yerde ölmelerini sağlamak şeklinde gelişme alanı yakalamıştır (Gomes vd., 2013). Bu nedenle, genel bir yargıyla hastanede ölmek, çoğunlukla mutlu ölümden oldukça uzak ve yetersizlik olarak değerlendirilmektedir (Earle vd., 2003). Diğer yandan, her ne kadar evde ölüm mutlu veya iyi olarak görülse dahi gelişmiş dünyada ölümlerin çoğunun hastanelerde ve bakım merkezlerinde meydana geldiği gerçeği de bilinmelidir (Broad vd., 2013; Cohen vd., 2015). Ancak her toplumun sosyo-kültürel özellikleri farklılaştığından ölüme ilişkin yarg1 ve yaklaşımları da değişmektedir. Gerek Türkiye'deki yaşam memnuniyeti araştırmalarında gerekse ulusal ya da uluslararası çoğu istatistikte "ölüm yeri"ne ilişkin yeterli bilgi bulunmamaktadır. Hayatı kısıtlayan bir hastalığı olan kişilerin çoğunlukla ikametlerine yakın bölge ya da yerel hastanelerde öldügü vurgulanan bir durumdur (WHO, 2014).

İkamet yeri dışında ölüm yerine gelmeden bireylerin bakımla iyileşme süreci, ölümün hanede gerçekleşmesi, kişinin tanıdık ve sevdiği kişiler arasında ölmesi olumlu ilişkiyi, ölüm şeklinin zor olması, ölümün ve ölüm yerinin tıbbileştirilmesi, bürokratikleştirilmesi gibi süreçler de iyi / mutlu ölümdeki olumsuz ilişkiyi arttırabilmektedir. Ölümdeki olumlu ve olumsuz ilişkiyi iyi ve mutlu ölüm açısından birbirinden ayırmak gerekmektedir. Palyatif bakım, ileri tıbbi müdahale gibi süreçlerle iyileştirilmeye çalışılan bireyin iyi ölüm süreci ile sevdikleri arasında, istediği yerde ölmesiyle ilişkili mutlu ölümü birbirinden ayırmak gerekmektedir. Kentsel yaşam pratikleri, hastane unsurları ve teknikleriyle iyileştirilmeye çalışılan bireyin iyi ve mutlu ölüm süreçlerinin aynı olmadığı sağlık araştırmalarında da sıklıkla geçmektedir (Institute 
of Medicine, 1997). Bu nedenle, kırsal alanda yaşlıların yaşam süreçlerinin geç dönemlerinde gerçekleşen ölümler çoğunlukla hastanede geçmektedir. Bu durum, kırsal ölüm süreçlerinin kentsel ilişkiler içinde, onlara benzer veya geleneksel yaklaşımlarla ve iyi ölümle açıklanma ihtiyacını artırmaktadır. Dolayısıyla, i) sağlık uzmanlarının iyileştirme çabasıyla birlikte, sağlık bakıcıları tarafından "iyi" hareket, farkındalık / farkında olmak, kabul ve ölüme hazırlık ve barışçıl, onurlu bir ölüm şeklinde tanımlanabilecek iyi ölüm ile ii) hastalar veya aileleri tarafından ölümün kabul edilmemesi veya ölüm anına kadar yaşamda istenmeyen, başarısız olarak sürdürülen genel çabalarla tanımlanabilen kötü ölümdeki kırsal farklılığın ortaya çıkarılması gerekmektedir. Yaşam sonu sürecinde mekânın duyguyla ilişkisi bağlamında ortaya çıkan ölüm yerinin mutlu ölümde geçerli tek sebep veya faktör olmad1ğını da belirtmeliyiz. Gerçekliği de ifade etmesi nedeniyle, ölüm ve mutluluk ilişkisinde, çevresel değerler, aile ilişkileri, yaşam kalitesi, inanç, demografik bilgiler, sosyo-ekonomik durumun etkileri bulunmaktadır. Ölümünden önce semptomların kötüleşme anına ve ailenin baş edemeyecek duruma gelmesine kadar ölmek üzere olan kişinin durumu ile mutlu ölüm arasında ilişki bulunmaktadır. Dolayısıyla, kırsal bölge sakinleri evde mi ölmek istiyor önyargısından ziyade, bu sakinlerin nerede iyi ve mutlu öldükleri çalışmanın odak noktası olacaktır. Bu çalışma, aynı zamanda kırsal alanda farklı unsurlar temelinde meydana gelen mutlu ölüme yönelik bir analizi içermektedir.

\section{Çalışmada Kullanılan Yöntem ve Teknik}

Ölümle ilişkili literatürün derinliklerine inildiğinde sınırlı çalışmaların kırsaldaki sesleri/ifadeleri, görünümü ve durumu temsil etmede önemli ölçüde yetersiz kaldığı görülmüşsür. Araştırma tasarlanırken değişkenler, sorular ve katılımcılar amacımıza uygun bir şekilde formüle edildi. Bu araştırmanın temel amacı, hayatı sınırlayan hastalığa sahip kırsal alandaki yaşlı bireylerde iyi ve mutlu ölüm kavramını araştırmaktır. Araştırma, hayatı kısıtlayan hastalıklara sahip 65 yaş ve üstü yaşlılara bakan/ilgilenen veya yakınında olan kişilerle yürütülmüştür. Çalışmada yaşlı kişilerin kendi deneyimlerini aktarmaları veya iyi ve mutlu ölümü ken- 
di yöntemleriyle tanımlamaları elbette önemliydi. Ancak iyi ve mutlu ölüm arasındaki ilişkiyi ortaya çıkarmak için ölüm olayı gerçekleşmiş olmalıydı. Bu nedenle, ölüm süreci öncesinden başlayarak çoğunlukla yanında bulunan, ilgilenen, bakımını üstlenen kişilerle araştırma yürütülmüştür. Yaşlıların iyi ve mutlu ölüm deneyimleri bu yöntemle öğrenilmiştir. Ölüm yeri olarak kırsal alanda ikamet ve iyi ölüm arasındaki ilişkinin bağlamı Batman ve Diyarbakır'da 102 kişiyle yürütülen araştırmaya dayandırılmıştır. Evde bakımın yanı sıra, hastane ve bakım ihtiyacı iyi ölüme bir kanıt olarak sunulmaktadır. Bu nedenle, 102 katılımcıyla yürütülen araştırmada mutlu ölüm ile iyi ölüm arasındaki farklılığı tespit etmek amaciyla "mutlu ölümde yüz ifadesi ve ölüm yerine" (Zhang ve $\mathrm{Lu}, 2017)$ ilişkin bilgiye önem verilmiştir. Yaşlıların öldüğ̈̈ yer ile iyi ölüm arasında ilişki kurulurken sağlık imkânlarının gelişmişliğinin önemine de ayrı vurgular yapılmaktadır (Dong vd., 2019).Güneydoğu Anadolu Bölgesi'nde sağlık imkanlarının, hızlı ulaşımın ve palyatif bakımın gelişmişliği beklentisiyle Batman ve Diyarbakır seçilmiştir. Kırsal alandan seçilen kişilerin ve yakınlarının sınırlı olanakları da mutlu ölümün olumsuzluğunu pekiştirebilmektedir. Ölüm yeri mutlak ve yeterli tek kanıt olmadığından iyi ve mutlu ölüm yaşlıların demografik, sosyo-ekonomik ve sağlık bilgileriyle değerlendirilmiştir.

2019'un ortalarında başlatılan çalışmada öncelikle, literatürdeki benzer çalışmaların temel iddia ve benzer vurgularına yer verilmiştir. Literatüre bakıldığında, öznel olarak vurgulanan iyi ölümde bireysel bakış açıları ve öncelikler öne çıkmaktadır (Rainsford vd., 2016). Çalışmada nicel yöntem anlayışı benimsenerek, yaşl1ların ölüm deneyimleri bakıcılarına yöneltilen anket formlarının yanı sıra mutlu ölüm ile kırsal ikamet yeri ilişkisi gözlemle de tespit edilmiştir. Analizlerde anket formundaki sorular ile gözlem notları birleştirilmiştir. Katılımcılar, i) farklı kırsal kesimlerden hastalık tipine sahip yaşlılar ile ii) eğitimli ve yüksek gelirli yaşlılar (eğitim ve gelir durumlarındaki farklılığı da gözlemlemek üzere) amacimıza uygun olacak şekilde yönlendirmelerle çok aşamalı olasılıklı bir örneklem tasarımına göre belirlenmiştir. Haziran ve Ağustos ayları arasında yürütülen çalışmada kişisel bilgiler an- 
ketle, vefat edenlerin yaşamlarının sonundaki fiziksel ve psikolojik belirtiler ise bireysel düzeyde gözlem notlarıyla toplanmıştır. Aynı şekilde, vefat edenlere yönelik hizmet kaynakları hakkında topluluk düzeyinde veriler kişisel gözlem notları literatürdeki tartışmalarla karşılaştırıldı.

Araştırmada, derin kültürel farklılıklar ortaya çıkmayacak şekilde kırsal bölge sakinlerinin yaş, cinsiyet, medeni durum, ikamet edilen yer ile yaşam sonu yeri ilişkisi, hayatı sınırlayan hastalık tipi benzerliklerinden hareketle iyi ölümün bağlı olduğu üç farklı değişken grubuna yer verildi. i) Demografik değişkenlerde ölüm yaş1, cinsiyet ve medeni durum, ii) eğitim ve hane geliri gibi değişkenlerle de sosyo-ekonomik durum ve son olarak, iii) ölüm nedeni olarak hastalık ve ağrı belirtileri/yüz ifadesi de sağlık değişkenleri olarak değerlendirildi. Araştırmada yaş, cinsiyet ve medeni durum gibi temel demografik veriler dikkate alınarak mutlu ölüm ve ölüm yeri olarak kırsal alanın çapraz ilişkisi kurulmaya çalışılmıştır. Ölüm nedeni ve ölüm yeri arasındaki farklılıklarla eksik ve yanlış veri analizinin oluşmamasına dikkat edilmiştir. Belirlenen katılımcı ve değişken sınırlarında ve bu sınırlar dışında, çalışmanın hazırlık ve veri toplama aşamaları ile katılımcıların ifadelerinde ölüm duygusuyla ilişkili pratik bağlamda çeşitli zorluklar yaşanmıştır.

\section{Ölüm Yeri, İyi Ölüm ve Mutlu Ölüm Arasındaki İlişkinin Ana- lizi}

Ölüm anında meydana gelen acıların evde daha düşük maliyetle rahatlatılabileceği, kültürel olarak tercih edilme olasılığı, erişme durumu, profesyonel bakıcıların bulunduğu bir hastanede olup olmadığı soruları oldukça önemlidir. Verilecek cevaplar sayesinde, yeterli bakım, yaşanılan yer ile yüksek kalitede iyi ve mutlu ölümün fizibilitesiyle ilgili politika yapıcılar, sağlık hizmeti sağlayıcıları, yaşlı yetişkinler ve aile üyeleri arasında diyalog da kolaylaştırılabilir (Kinoshita vd., 2014). Böylece, toplumumuzda evde ölüm ile hastanede ölüm karşılaştırıldığında hangisinin daha yüksek iyi ve mutlu ölüm kalitesine sahip olduğu ortaya çıacaktır.

Türkiye'de kırsal alanda ölen yaşlıların deneyimlerini aktarama- 
yacağından ve söz konusu durumu nüanslı bir anlayışla sunma isteği nedeniyle, yöntem kısmında değinildiği üzere sorulardan elde edilen verilerin analizi ile araştırma sonucu bakıcının cevaplarına göre ifadeleşmiştir. Araştırma verileri, yaş ve cinsiyete göre farklılaşırken, uzun dönemli hastalık durumunda (5 sene ve üzeri) gelir ve eğitim bağlamında sosyo-ekonomik olarak sağlık olanaklarına erişimde farklılaşmalar sebebiyle yer yer eşitsizlikler görülmüştür.

Tablo 1: Yaşlıların Ölüm Yaşı ve Cinsiyet Durumları

\begin{tabular}{|c|c|c|c|c|c|c|}
\hline \multirow{3}{*}{ Ölüm Yaşı } & \multicolumn{6}{|c|}{ Cinsiyet } \\
\hline & \multicolumn{2}{|c|}{ Kadın } & \multicolumn{2}{|c|}{ Erkek } & \multicolumn{2}{|c|}{ Toplam } \\
\hline & $f$ & $\%$ & $f$ & $\%$ & $f$ & $\%$ \\
\hline $65-74$ yaş arası (a) & 10 & 9,80 & 34 & 33,33 & 44 & 43,13 \\
\hline 75 - 84 yaş arası (b) & 15 & 14,70 & 21 & 20,58 & 36 & 35,29 \\
\hline 85 - 94 yaş arası (c) & 17 & 16,66 & 3 & 2,94 & 20 & 19,60 \\
\hline 95 yaş ve üstü (d) & 2 & 1,96 & - & - & 2 & 1,96 \\
\hline Toplam & 44 & 43,13 & 58 & 56,86 & 102 & 100 \\
\hline
\end{tabular}

Toplumsal hayatın önemli bir parçası olan eşitsizlik sağlığa erişim ve refah olanaklarıyla ilişkili bir şekilde kadın ve erkek ölümlerini de etkilemektedir (Schünemann vd., 2016). Ağır ve ölümcül hastalıklar sebebiyle hastanede tedavi görme ve bu sebeple ölüm olay1nın çoğunlukla erkeklerde görüldüğünü söylemek mümkündür. Tablo 1'de görüldüğü üzere, her iki cinsiyetin farklı dönemlerinde ölüm hızlarında değişimler söz konusudur. Kırsal alanlarda yaşlılığın erken dönemlerinde aile tercihleri ve değer algıları gibi cinsiyetler arasında farklı belirleyicilerin değişimde etkili olabileceğini söylemek gerekir. Türkiye gibi gelişmekte olan ülkelerde sağlık hizmet ve koşullarına bağlı uzun ömürdeki farklılıklar yalnızca yaştan kaynaklı bir durum olmayıp, kişilerin cinsiyetine göre iş ve davranış şekilleriyle de ilgilidir. Gelişmiş ülkelerde kadınların erkeklerden yaklaşık 4-5 yıl daha uzun yaşaması beklenen bir durumdur (Schünemann vd., 2016). Dolayısıyla, yaşlanma cinsiyetten bağımsız olmadığı gibi, ölüm de cinsiyetten bağımsız değildir. Dünya doğum ve ölüm demografik değişim istatistikle- 
ri incelendiğinde ve bu veriler sağlık koşullarıyla birlikte değerlendirildiğinde erkeklerin yaşam kursunun erken aşamalarında kadınlardan daha yüksek ölüm oranlarına sahip olduğu ortaya çıkacaktır (Verbrugge, 1985). Küresel ölçekte kadınların lehine bir durum yaşandığı, hemen hemen her ülkede yaşlı kadınların çoğunlukta olduğu söylenebilir (Carr ve Deren, 2009). Sonuç olarak, bu boşluğun büyüklüğü yaşam seyri ve bölgeler arasında değişmekle birlikte, neredeyse her ülkede kadın yaşam beklentisi erkek yaşam beklentisinden daha yüksektir. Uzun yaşam beklentisi yalnızca cinsiyetle ilişkili değildir. Aynı zamanda eğitim ve gelir durumunun gelişmişliğiyle de ilişkilidir.

Tablo 2: Yaş ve Cinsiyete Göre Eğitim Durumu

\begin{tabular}{|c|c|c|c|c|c|c|}
\hline \multirow[b]{3}{*}{$\begin{array}{l}\text { Ölüm } \\
\text { Yaşı }\end{array}$} & \multicolumn{6}{|c|}{ Cinsiyete Göre Eğitim Durumu } \\
\hline & \multicolumn{3}{|c|}{ Kadın } & \multicolumn{3}{|c|}{ Erkek } \\
\hline & $\begin{array}{l}\text { İlköğretim } \\
\text { ve altı }\end{array}$ & $\begin{array}{l}\text { Orta- } \\
\text { öğretim }\end{array}$ & $\begin{array}{l}\text { Lisans } \\
\text { ve üstü }\end{array}$ & $\begin{array}{l}\text { İlköğretim } \\
\text { ve altı }\end{array}$ & $\begin{array}{l}\text { Orta- } \\
\text { öğretim }\end{array}$ & $\begin{array}{l}\text { Lisans } \\
\text { ve üstü }\end{array}$ \\
\hline $\begin{array}{l}65-74 \\
\text { yaş arası }\end{array}$ & 6 & 3 & 1 & 20 & 8 & 6 \\
\hline $\begin{array}{l}75-84 \\
\text { yaş arası }\end{array}$ & 13 & 2 & - & 11 & 6 & 4 \\
\hline $\begin{array}{l}85-94 \\
\text { yaş arası }\end{array}$ & 17 & - & - & 2 & 1 & - \\
\hline $\begin{array}{l}95 \text { yaş } \\
\text { ve üstü }\end{array}$ & 2 & - & - & - & - & - \\
\hline Toplam & 38 & 5 & 1 & 33 & 15 & 10 \\
\hline
\end{tabular}

Yaşam alanında ilerici bir gelişme olarak adlandırabileceğimiz yaşlılıkta eğitim sosyal refah üzerinde önemli bir etkiye sahiptir. Lisans ve üzeri nitelikli eğitim derecesine sahip yaşlılar, sosyal refah olanaklarına ulaşım açısından diğerlerine göre daha avantajl1dır (Singh ve Kiran, 2015). Araştırma amacına uygun şekilde seçilen yüksek eğitimli kişilerin bilinçli davranışları sayesinde fiziksel sağlıkları sosyalleşme yeteneklerini sınırlamamaktadır. Lise öğrenimini görmüş yaşlılar diğerleriyle ilişkilerini sürdürmek zorunda olmadıklarını düşünmektedirler. Aktif sosyalleşmenin daha iyi eğitim yoluyla mümkün olduğunu gösteren sosyolojik teorilerde 
de geçtiği üzere (Lewis, 2010), gözlemlerde yaşlıların bir kısmının daha kabul edilebilir olmasının da eğitimin sosyal refah ve bakım olanaklarıyla paralel olduğu ortaya çıkmıştır. İlköğretim ve altı eğitim grubundaki 8 kişinin de istisnai bir biçimde sağlık, bakım ve sosyal ilişkiler bağlamında bilinç düzeyinin yüksek olduğu gözlemlenmiştir.

Tablo 3: Yaşlıların Yaşadığ1 Hanenin Gelir Durumu

\begin{tabular}{|c|c|c|c|c|c|}
\hline \multirow[b]{2}{*}{$\begin{array}{l}\text { Hane gelir } \\
\text { durumu }\end{array}$} & \multicolumn{5}{|c|}{ Yaş grubu } \\
\hline & $\begin{array}{c}65-74 \\
\text { yaş arası }\end{array}$ & $\begin{array}{c}75-84 \\
\text { yaş aras1 }\end{array}$ & $\begin{array}{c}85-94 \\
\text { yaş aras1 }\end{array}$ & $\begin{array}{r}95 \text { yaş } \\
\text { ve üstü }\end{array}$ & Toplam \\
\hline 2324 ve altı & 5 & 2 & 3 & - & 10 \\
\hline $2325-4999 \mathrm{TL}$ & 28 & 18 & 15 & 1 & 62 \\
\hline $5000-9999 \mathrm{TL}$ & 11 & 16 & - & 1 & 27 \\
\hline 10000 TL ve üstü & - & 1 & 2 & - & 3 \\
\hline Toplam & 44 & 36 & 20 & 2 & 102 \\
\hline
\end{tabular}

Aile desteği alan katılımcıların durumları düşünülerek verilerin bir bölümü analiz edilmiştir. Bu durumda kırsal alanda yaşayan yaşlılarda ekonomik olarak aile desteğinin iç ve dış bakım ile ilişkilerinde önemli olduğu ortaya çıkmıştır. Destekle daha iyi bakım alabilmekte ve ölüme yakın daha iyi bir yaşam geçirebilmektedir. Yaşlıların önemli bir kısmı uzunca bir süre kırsal çalışma hayatından çekilmemiş olsalar da emekli olamamış ve kısmen ekonomik bağımlılık yaşamışlardır.

Tablo 4: Katılımcıların Öz Bakımları

\begin{tabular}{|c|c|c|c|c|}
\hline \multirow{3}{*}{$\begin{array}{l}\text { Öz } \\
\text { bakım }\end{array}$} & \multicolumn{4}{|c|}{ Cinsiyete göre eğitim durumu } \\
\hline & \multicolumn{2}{|c|}{ Kadın } & \multicolumn{2}{|c|}{ Erkek } \\
\hline & $\begin{array}{c}\text { İlköğretim ve } \\
\text { altı }\end{array}$ & $\begin{array}{c}\text { Ortaöğretim } \\
\text { ve üstü }\end{array}$ & $\begin{array}{c}\text { İlköğretim ve } \\
\text { altı }\end{array}$ & $\begin{array}{c}\text { Ortaöğretim } \\
\text { ve üstü }\end{array}$ \\
\hline Yeterli & 7 & 4 & 9 & 8 \\
\hline Yetersiz & 31 & 2 & 24 & 17 \\
\hline Toplam & 38 & 6 & 33 & 25 \\
\hline
\end{tabular}


Yüksek eğitim ve emeklilik ilişkisi ekonomik bağlamda servet birikimine yol açsa da katılımcıların bir bölümünde bakımda yetersizliğe neden olmuştur (Prins ve Schafft, 2009). Bu durumda, eğitim ve ekonomi değişkenleri birlikte ele alındığında yüksek eğitimlilerin servet birikimine de sahip oldukları, ancak az da olsa bunların bir bölümünün bakım yetersizliği sebebiyle olumsuz koşullarda yaşadıkları görülmüştür. Literatürde yaşlı bireylerin ilerleyen dönemdeki servet ve sermaye birikimi ile ekonomik bağımlılıklarına ilişkin durumları bireyselci açıklamalar (alkol bağımlılığı, tembellik, tasarruf eksikliği), toplumsal faktörlerin nedensel önemine odaklanan yapısal (ayrımcılık, düşük okul, düşük ücret) ve kaderci niteliklerle (kötü şans, talih) açıklanmaktadır (Bullock, 2006:4). Katılımcıların bir bölümünün çocukluk çağında eğitim kurumlarının eksikliği ve çalışma çağında nitelikli işlerin eksikliği sebebiyle hem ekonomik sermaye birikimleri hem de öz bakımlarında yetersizlikler olduğu görülmüştür.

Tablo 5: Cinsiyete Göre Medeni Durum

\begin{tabular}{|l|c|c|c|}
\hline \multirow{2}{*}{ Medeni durum } & Kadın & Erkek & Toplam \\
\cline { 2 - 4 } & 7 & 52 & 59 \\
\hline Evli & 2 & 1 & 3 \\
\hline Bekar & 35 & 5 & 40 \\
\hline Dul & 44 & 58 & 102 \\
\hline Toplam & & & \multicolumn{3}{|c|}{ Cinsiyet } \\
\hline
\end{tabular}

Yaşlıların medeni durumu; eşinin yaşıyor oluşu veya vefat etmiş olması yaşam seçim ve beklentilerini birbirinden farklılaştırmaktadır. Halen evli, dul ve bekârlar arasında ölümde farklılaşmalar bulunmaktadır. Evli ve eşi yaşayan insanların ölüm oranlarını diğerlerinden farklı olarak açıklayan üç teori bulunmaktadır. İlkinde evliliğin ölüm üzerindeki seçim etkisine (Livi-Bacci, 1984), diğerinde evliliğin ölüm üzerindeki koruyucu rollerine odaklanılmaktadır (Glenn ve Weaver, 1988; Wu ve Hart, 2003). Son teoride, evli insanların evli olmayanlara göre sağlık avantajları nedeniyle daha uzun yaşadığı varsayılmaktadır (Lillard ve Panis, 1996). Ka- 
dınların eşi vefat etmişse ilk yaklaşımda olduğu gibi mutlu bir şekilde ölüneceği belirtilerek, ölüm tercih edilmektedir. Ancak bu durumun aksine ölüm durumunda geride sevilen veya bağımlı kişiler varsa koruyucu etkiyle ölüm tercih edilmemektedir. Geride kalanları koruma isteği nedeniyle mutlu ölümden uzaklaşılmaktadır. Hastalığın ağırlaştığı durumlarda ise kendi kurtuluşu ve bakıcının rahat etmesi için ölüm istenmektedir. Ancak söz konusu durum iyi olsa da mutlu bir ölüm olduğu söylenemez. Evlilik durumu stresi azalttığından, sağlıklı yaşam ve bakım gibi kombine etkilerle koruyucu olabilmektedir. Bir başka şekilde, mutlu ölüm kolaylaşması ise çoğunlukla eşi önceden vefat edenin kavuşma hissiyatıyla olabilmektedir.

Tablo 6: Yaşlıların Ölüm Yeri

\begin{tabular}{|l|c|c|c|c|}
\hline \multirow{2}{*}{ Ölüm yeri } & \multicolumn{4}{|c|}{ Cinsiyet } \\
\cline { 2 - 5 } & \multicolumn{2}{|c|}{ Kadın } & Mutlu & Mutsuz \\
\hline & Mutlu & Mutsuz & 12 & 4 \\
\hline İkamet yeri & 10 & 2 & 37 & 5 \\
\hline İkamet yeri dışında & 25 & 7 & 49 & 13 \\
\hline Toplam & 35 & 9 & & \\
\hline
\end{tabular}

Ölüm yeri çoğu insanın evde ölmeyi tercih edeceği inancına dayanarak (Saunders, 2012), yaşam sonu bakım kalitesinin önemli bir göstergesi haline gelmiştir (Gomes vd., 2013; Waghorn vd., 2011). Mutlu ölümün farklılaşmasına bakmak için ikamet yerinde ve ikamet yeri dişında (hastane, başka birinin evi, bakım merkezi vb) ölenler şeklinde iki grup incelenmiştir. Gözlemler neticesinde yaşlıların çoğunlukla sevdiklerine ve yakınlarına yakın yerlerde mutlu öldükleri ortaya çıkmıştır.

Toplumsal değişimin de bir sonucu olarak insanlar giderek yaşadıkları yerlerden uzaklaşmaktadır. Yaşlılığa doğru sevdikleri kişilerden uzaklaşma şeklinde gerçekleşen bu durumda ev yerine farklı kurumlara yerleşmeye veya yerleştirilmeye başlamaktadırlar. İnsanların ömürlerinin önemli bir bölümünü farklı kurumlar- 
da geçireceği bilinse de bakım kalitesinin düşük olması endişeleri nedeniyle (Brereton vd., 2012; Leadbeater ve Garber, 2010) hastane koğuşları ile bakım yerlerinin kurumsal ortamı (Pollock, 2015), ölmek için uygun olmayan ve istenmeyen yerler olarak kabul edilir. Sağlıklı yaşam ve davranışlar için mükemmel destek birimleri haline getirilen hastanelerde ölümün iyi olması istense de her zaman mutlu olduğunu göstermemektedir. Ölüm öncesi için postmodern bir bakım hareketi olarak alternatif yerler, deneyimler ve genellikle iyileştirici tıpla karşılaştırılan sosyal bakım toplumsal bir yaklaşımla ele alınmalıdır. Ölmekte olan kişinin bulunduğu veya ölümün gerçekleştiği yerle ilgili tıbbi ve bürokratik koşullarda önemlidir. Sosyal bakım, böylesi koşullara tepki olarak ortaya çıkmıştır. Sosyal bakım bir bağlamda modern hastanede ölümle yaşanan acı ve adaletsizliklere tepkinin bir biçimidir (Palgi ve Abramovitch, 1984). Bu nedenle, sosyal bakımla hastaların bütünsel olarak farklı fiziksel, duygusal sosyal ihtiyaçları karşılanmaya çalışılmakta, yaşam kaliteleri arttırılarak, ölüm üzerinde hafifletme sağladığından (Short ve diğerleri, 1993, s.117) hem akademik çevrede hem de sosyal ilişkiler bağlamında daha uygun, iyi ve mutlu ölümle bağdaştırılmaktadır. Hayatı sınırlayan hastalıklar için hastaneler iyi ölüm yerleri olarak düşünülebilir. Bakım kadar, bireyin taşıdığı hastalık ve hastalığa bağlı acılar da iyi ve mutlu ölüm şeklini etkileyen sebeplerdendir.

Tablo 7: Hastalık ve Ölüm Yeri İlişkisi

\begin{tabular}{|l|c|c|c|}
\hline \multirow{2}{*}{ Ölüm yeri } & \multicolumn{2}{|c|}{ Cinsiyet } & \multirow{2}{*}{ Toplam } \\
\cline { 2 - 3 } & $\begin{array}{c}\text { İkamet } \\
\text { yeri }\end{array}$ & $\begin{array}{c}\text { İkamet yeri } \\
\text { dışında }\end{array}$ & \\
\hline Kanser & 10 & 29 & 39 \\
\hline Beyin ve sinir hastalıkları & 3 & 5 & 8 \\
\hline Kalp ve damar hastalıkları & 7 & 16 & 23 \\
\hline Solunum sistemi hastalıkları & 2 & 9 & 11 \\
\hline Ortopedi ve travmatoloji hastalıkları & 4 & 6 & 10 \\
\hline Diğer hastalıklar & 2 & 9 & 11 \\
\hline Toplam & 28 & 74 & 102 \\
\hline
\end{tabular}


Yaşlıların ikamet özellikleri ve ölüm yeri arasındaki ham ilişkilere dayanarak, hastanın kendi konutunu özel olarak tercih sebebi ve taşıdıkları hastalıklar gruplandırılarak tabakalaştııılmıştır. Kırsal alandaki yaşlıların önemli bir bölümünün kanser ve kalp damar hastası olduğu görülmüştür. Başta kanser, sonrasında da kalp damar hastalıkları nedeniyle ikamet yeri dışında vefat oranlarının daha yüksek olduğu görülmektedir. Yaş ilerledikçe ikamet yeri dışında ölüm oranları giderek düşmekte, evli ve eşi halen yaşayanların ölümleri de çoğunlukla hastanede gerçekleşmektedir. Yaş, cinsiyet ve medeni durum evde doğal ölümler ile kanser ölümlerini önemli ölçüde etkilemektedir. Yaş, cinsiyet ve medeni durumun yanı sıra yaşam koşulları, ortak dayanışma, statü, değerler, ortak inanışlar yani genel olarak sosyo-ekonomik durum iyi veya mutlu ölümü etkileyen temel sebepler arasında yer almaktadır. Nitekim, Weberian geleneğe göre sosyo-ekonomik durum, ortak inançları, değerleri ve yaşam koşullarını paylaşan insan gruplarını da ifade ettiğinden (Lynch ve Kaplan, 2000), sosyal tabakalaşmanın yalnızca ekonomik mallar, eğitim veya yaşam koşulları gibi tipik bir dizi faktöre atıfta bulunmadığını kabul eder. Bununla birlikte, toplumlar tarafından paylaşılan sosyal statü, ailevi dayanışma veya yaşam tarzı da bu sistemde sosyo-ekonomik durumla ilişkili olup, iyi ölümü etkilemektedir (Galobardes vd., 2007). Kirsallık düzeyi ile bölgedeki doktorların yoğunluğu yaşlıların ikamet yerinde ölümünü etkileyen önemli diğer etkenlerdendir. İkamet yerinde ölüme ilişkin en çarpıcı varyasyon serbest meslek sahibi işçiler, alt gelirli çiftçiler, mavi yakalı çalışanlardan veya işçi sınıfından kişilerin yine kanser olma durumudur. İkamet yeri dışında ölenler çoğunlukla üst eğitim ve gelir grubundaki orta ve üst sınıfa mensup kişilerden oluşmaktadır. Aynı şekilde, bu tabakaya yakın veya mensup kendi işinin sahibi olan sermaye biriktirmiş kişiler çoğunlukla kanser ve solunum hastasıdır. Bu gruptakilerin büyük bölümü ileri yaş grubunda yer almaktadır. Üst yaş ve gelir grubundaki katılımcıların önemli bir bölümü evde ölme isteğinde olmuşlardır. Söz konusu gruptaki yaşlıların evde ölüm isteği kültürel ve iyi ölüm tercihleriyle açıklanabilir. 
Tablo 8: Hastalık ve Ölen Kişilerin Yüz İfadesi

\begin{tabular}{|l|c|c|c|c|c|}
\hline \multirow{2}{*}{ Hastalık grubu } & \multicolumn{5}{|c|}{ Yüz ifadesi (Acı veya huzur belirtisi) } \\
\cline { 2 - 7 } & $\begin{array}{c}\text { Tamamen } \\
\text { acı verici }\end{array}$ & Acı verici & Belirsiz & Huzurlu & $\begin{array}{c}\text { Oldukça } \\
\text { huzurlu }\end{array}$ \\
\hline Kanser & 12 & 15 & 2 & 8 & 2 \\
\hline $\begin{array}{l}\text { Beyin ve sinir } \\
\text { hastalıkları }\end{array}$ & - & 3 & 1 & 1 & 3 \\
\hline $\begin{array}{l}\text { Kalp ve damar } \\
\text { hastalıkları }\end{array}$ & 1 & 8 & 5 & 6 & 3 \\
\hline $\begin{array}{l}\text { Solunum sistemi } \\
\text { hastalıkları }\end{array}$ & - & 5 & - & 5 & 1 \\
\hline $\begin{array}{l}\text { Ortopedi ve } \\
\text { travmatoloji } \\
\text { hastalıkları }\end{array}$ & 1 & 4 & - & 3 & 2 \\
\hline Diğer hastalıklar & - & 5 & 1 & 2 & 3 \\
\hline Toplam & 14 & 40 & 9 & 25 & 14 \\
\hline
\end{tabular}

Sosyal davranışın temel bileşenlerinden biri, duygusal yüz ifadesidir. Ölüm deneyiminin bir ölçütü olarak, ölümdeki yüz ifadesinde acı ve huzura ilişkin cevaplar gözlemlerle değerlendirilmiştir. Ölen kişinin ölüm yeri ile yüz ifadesinden hareketle iyi ölümü tanımlamak üzere pozitif ve negatif ayrık terimler kullanılmıştır. Tarafsız yüzleri ayırt etmede güçlükler yaşansa da (Felmingham, Bryant ve Gordon, 2003) katılımciların önemli bir bölümünde korkulu, dehşetli, acı verici, hüzünlü, mutlu gibi ifadeler sosyal yaşantılarının ya da son dönem yaşadıklarının bir kanıtları olarak gözlemlenmiştir. Dolayısıyla, üzgün, mutlu, öfkeli gibi duyguyla ilişkili ve ayrık ifadeler yalnızca yaşayan insanlar için değil, aynı zamanda ölen insanların mutluluk durumunu tanımlamak için de kullanılabilir (Eyetsemitan ve Eggleston, 2002). Onun için hayatı sınırlayan hastalıkların acısı iyi ölümü değil, kötü ölümü kanıtlamaktadır. Çoğu çalışmada da geçtiği gibi insanlar yas sürecinin bir parçası olarak ölen kişinin görünüşünü ve yüz ifadesini önemsemektedir (Worden, 1991). Hatta bu nedenle,kişinin iyi veya kötü öldüğü belirtilmektedir. Ölen kişi erken yaş döneminde sosyo-ekonomik olarak güçlü bir kişiyse, yüzünde algılanan duygu olumluysa, sağlıklı bir yas yörüngesi ve eğer negatifse sağlıksız 
bir yas yörüngesi olasıdır. Ölümde gözün kapalı oluşu mutluluk ve huzurla ilişkilendirilerek yas sürecinde de hatırlanıp sevinilmektedir. İkamet yeri dışında ölenlerin yüz ifadesi ise negatif bir ayrımla hatırlanarak, ölen kişinin tanıdıkları bu durumu hatırlayarak yas sürecinde daha zayıf düşmektedir. İkamet yeri dışında nitelikli bir bakımla ölenler ise pozitif bir yüz ifadesiyle hatırlanmaktadır. Hastalığın şiddeti, artan stres ve sağlık bakımındaki sorunlar acıyı artırmaktadır. Ölen kişinin geride evlenmemiş çocuğu varsa, yas sürecinde "mürüvvetini göremeden gitti" şeklindeki ifadelerde bulunulur, "hac görevini yerine getirmemişse" mutlu bir ölümün gerçekleşmediği beyan edilir. Kişinin ekonomik durumu iyiyse yas sürecinde de iyi hatırlanır ve iyi öldüğü belirtilir. Dolayısıyla ölen yaşlıların ölüm yeri ile iyi / mutlu ölüm ilişkisini yalnızca bir değişkene dayanarak açılamak mümkün değildir. Ölen kişilerin her bir özelliği diğer özellikleriyle etkileşimli olduğundan ölüm durumları da bu şekilde açıklanmıştır.

\section{Sonuç}

Gelecekte uzun dönemli bakım imkânlarının gelişmesiyle, bakım merkezleri ve hastanelerde artan sayıda yaşlı yetişkinin ölmesi mümkün görünmektedir. Şu anda ve gelecekte artan sayıda gerçekleşmesi beklenen ikamet yeri dışındaki ölümlerin önemli bir kısmı iyi ölüm olarak tanımlansa da araştırmada elde edilen sonuçlara göre çoğunlukla mutlu ölüm olarak tanımlanmamaktadır. İyi ve mutlu ölüm tanımlamaları arasında ortaya çıkan farklılaşmanın iki önemli sebebi bulunmaktadır. Bu farklılaşmanın temel sebeplerinden ilki, kırsal çevrede yaşayan yaşlı nüfusun kültürel değer ve kodlarından kopamamasıdır. İkincisi de kırsal çevredeki nüfusun temel demografik ve sosyo-ekonomik özellikleri yavaş değişse de hastane ve benzeri yerlerde bürokratik ve kurumsal dönüşümün hızlı bir şekilde gerçekleşmesidir. Yaşlıların çevresel ilişki ve davranışlarından kopamaması, değerlerini devam ettirmek istemesi ve bunların ana akım tıp ile tıbbın teknik baskısıyla ihlal edileceği korkusu alternatif prensiplere yöneltmektedir. Böylece, ölüm yeri olarak hastane örgütsel ve profesyonel olmakla birlikte, yükselen sosyal koşullar ve mutlu ölüm çoğunlukla kişilerin temel özelliklerine bağlıdır. 
Sosyo-ekonomik durumu daha yüksek olan kişilerin evde ölme tercihlerinin onurlandırılma olasılığı, ölüm yeri tercihleri ve kişiler arası sağlık davranışlarındaki eşitsizlikler açısından başka bir önemi ortaya koymaktadır. Son zamanlarda yapılmış çalışmalardaki klinik, sosyo-demografik, mesken (kırsallık ve kentleşme düzeyi) ve sağlık sistemi (Bölgedeki mevcut hekim ve hastane yatak sayısı) gibi faktörlere dayanan araştırmalar benzer biçimde bu çalışmada da ölme modelleri (iyi, kötü ve mutlu ölüm) eğitim ve gelir durumu gibi sosyo-ekonomik konumu ifade eden özelliklerle açıklama ihtiyacı yükselmiştir. Weberian sistemdeki meslek, yaşam modelleri, inançlar ve değerlerin de yaşanılan yerle ve iyi ölümle ilişkili olduğu ortaya çıkmıştır. Tıbbın teknik ve teknolojileriyle daha iyi sağlık imkânlarından yararlanabilen üst sınıftaki insanlar kültürel kaynaklarıyla ölüm yerini doktor kontrolünde "evde ölüm" isteğiyle yönlendirebilmektedir. Alt ve orta sınıfta ise hastanede ölümün gerçekleşmesi duyguyla da ilişkilendirildiğinde çoğunlukla mutlu olmayan bir ölüm beklentisi ortaya çıkmıştır. Kırsal alanda sınıflar arasında iyi ölüm tercihlerinde bir dizi inanç, ailevi dayanışma, gelir durumu ve eğitimin çapraz ilişkisi olduğu ortaya çıkmıştır. Eğitimin sosyal refahla önemli ölçüde ilişkili olduğu, eğitimli yaşlıların daha yüksek düzeyde sosyal uyumu olduğunu da ortaya koymuştur.

Araştırma genel bulguları ve gözlem sonuçları birlikte değerlendirildiğinde, ölümcül hastalar ile onların yakın çevresindekiler ölüm olayının yakın bir zamanda gerçekleşeceğini bilselerdi, ölümün evde gerçekleşmesinin tercih sebebi olacağı söylenebilir. Nitekim ekonomik ve kültürel imkanlarla gelişmiş sağlığa erişebilen üst sınıfta söz konusu durum daha mümkün görünmektedir. Hastalığın ağırlaşmasıyla tedaviye erişebilirlik, ulaşımda sıkıntılarla kanser, sinir sistemi gibi ağır hastalık durumlarında evde ölmenin de her zaman en iyi seçenek olmadığını ortaya çıkarmıştır. Genel olarak, kanser hastaları daha iyi öngörülebilir bir hastalık seyrine sahip değil ve bu yüzden bu gruptakilerin büyük bölümü hastanede bakımın zorunluluğunu da bilmektedir. Bu hastalığa sahip yaşlılar ikamet yeri dışında öleceklerini de bilmekte veya tahmin edebilmektedir. Ancak her ne kadar kişiler ölme olasılıklarını ve 
ölüm dönemlerini bilseler de mutlu olmayan zorunlu bir hastane tercihi yoğunlaşmaktadır. Tedavisi artık tamamen sonlandırılan ve hastalık seyri öngörülemeyen yaşlıların ölümü bunun dişında tutulmalıdır. Bu grup çoğunlukla evde ölmeyi tercih ettiğinden mutlu öldükleri de belirtilmiş ve bu durumun duygusal yüz ifadelerine de yansıdığı söylenmiştir. Sonuç itibariyle, insanların büyük bir çoğunluğunun evde ölme tercihine rağmen, ülkemizde ölen yaşlıların ancak dörtte birinden az bir kesimin ikamet yerinde mutlu öldüğ̈ü söylenebilir.

Araştırmada ortaya çıkan önemli bir başka sonuç, yukarıda belirtildiği üzere, tüm gruplarda mesleki sınıf ve ölüm yeri arasındaki ilişkinin tam anlamıla ortaya çıkarılamamasıdır. Dolayısıyla, sınıf analizi ve ölüm yeri ilişkisi yaşam tarzı ve aile dayanışmasıyla daha muhtemel olduğundan mutlu ölümdeki dağılımın hem benzer hem de farklı değişkenlerle derinlemesine bir şekilde farklı çalışmalarla da netleştirilmesi gerekir. Hem bu çalışma hem de yapılacaklar, mevcut kırsal literatür ve Bölgeyle ilgili tanımlanmamış veya eksik tanımlanmış boşlukların da gözden geçirilmesini sağlayacaktır. 
Serdar Nerse

\section{Kaynakça}

Blauner, R. (1966). Death and social structure. Psychiatry, 29, 378394.

Brereton, L. vd. (2011). The hospital environment for end of life care of older adults and their families: An integrative review, Journal of Advanced Nursing, 68(5), 981-993.

Broad, J. vd. (2013). Where do people die? An international comparison of the percentage of deaths occurring in hospital and residential aged care settings in 45 populations, using published and available statistics. Int J Public Health, 58, 257-267.

Bullock, H. (2006). Justifying inequality: a social psychological analysis of beliefs about poverty and the poor, National Poverty Center Working Paper Series, \#06-08, USA.

Carr, D. ve Deren, S. B. (2009). Gender, aging and widowhood, P. Uhlenberg (ed.), in International Handbook of Population Aging, DOI 10.1007/978-1-4020-8356-3_32.

Cohen, J., vd. (2015). International study of the place of death of people with cancer: a population-level comparison of $14 \mathrm{co}-$ untries across 4 continents using death certificate data. British Journal of Cancer, 113, 1397-1404.

Corr, C. A., Kenneth, J. D. ve Kastenbaum, R. (1999). Dying and its interpreters: a review of selected literature and some comments on the state of the field. Omega, 39, 239-259.

Dong, T. vd. (2019). Association between dying experience and place of death: Urban-rural differences among older Chinese adults, Journal of palliative medicine, 20(20), 1-9.

Durkheim, E. (2011). Dini hayatın ilkel biçimleri. Eskiyeni yayınları.

Earle, C.C., vd. (2003). Identifying potential indicators of the quality of end-of-life cancer care from administrative data. Journal of Clinical Oncology, 21, 1133-1138.

Eyetsemitan, F. V. ve Eggleston, T. (2002). The faces of deceased persons as emotion-expressive behaviors: implications for mourning trajectories, OMEGA Journal of Death and Dying, 44(2), 151-167. 
Faunce, W. ve Fulton, R. (1958). The sociology of death: a neglected area of research. Social Forces,36, 205-209.

Felmingham, K. L., Bryant, R. A., ve Gordon, E. (2003). Processing angry and neutral faces in post-traumatic stress disorder: An event-related potentials study. Neuro Report: For Rapid Communication of Neurosci-ence Research, 14, 777-780.

Galobardes, B., Lynch, J. ve Davey, S. G. (2007). Measuring socioeconomic position in health research, Br Med Bull, 81(2), 21-37.

Glaser, B. ve Anselm, S. (1965). Awareness of dying. Chicago, IL: Aldine.

Glenn, N. D. ve Weaver, C. N. (1988). The changing relationship of marital status to reported happiness, Journal of marriage and the Family, 50, 317-324.

Gomes, B., vd. (2013). Heterogeneity and changes in preferences for dying at home: a systematic review. BMC Palliative Care, 12:7.

Institute of Medicine. (1997). Approaching death: improving care at the end of life. Washington, DC: The National Academies Press.

Kinoshita, H., vd. (2014). Place of death and the differences in patient quality of death and dying and caregiver burden. J Clin Oncol, 33, 357-363.

Leadbeater, C. ve Garber, J. (2010). Dying for change, London: Demos.

Lewis, G. M. B. (2010). Education and learning fort he elderly: Why, how, what. Educational Gerontology, 36(3), 213-228.

Lillard, L. A. ve Panis, C. W. (1996). Marital status and mortality: the role of health, Demography Journal, 33, 313-327.

Lynch, J. ve Kaplan, G. (2000). Socioeconomic position, In Social epidemiology, s. 13-35, New York: Oxford University Press.

Livi-bacci, M. (1984). Selectivity of marriage and mortality: Notes for future research, in Population and Biology, (Ed.) N. Keyfitz, 99-108, Liege, Belgium: Ordina Editions. 
Palgi, P. ve Abramovitch, H. (1984). Death: a cross-cultural perspective. Annual Review of Anthropology, 13, 385-417.

Pine, V. (1977). A socio-historical portrait of death education. Death Education, 1, 57-84.

Pine, V. (1986). The age of maturity for death education: A sociohistorical portrait of the era 1976-1985, Death Studies, 10, 209-231.

Pollock, C. (2015). Is home always the best and preferred place of death?, BMJ: British Medical Journal, 351:h4855, DOI: $10.1136 /$ bmj.h4855.

Prins, E., ve Schafft, K. A. (2009). Individual and structural attributions for poverty and persistence in family literacy programs: The resurgence of the culture of poverty, Teachers College Record, Vol:111, 2280-2310.

Rainsford, S., vd. (2016). Rural residents' perspectives on the rural 'good death': a scoping review. health and social care in the community. Helath and Social Care, 26(3), 273-294.

Saunders, D. C. (2012). End of life care strategy, founder of the modern hospice, Movement Fourth Annual Report, Sağlık Departman1, 12.08.2019 tarihinde https: / / assets.publishing.service.gov.uk/government/uploads / system/uploads / attachment_data/file/136486/End-of-Life-Care-Strategy-FourthAnnual-report-web-version-v2.pdf adresinden alınd1.

Schünemann, J., Strulik, H. ve Trimborn, T. (2016). The gender gap in mortality: how much is explained by behavior?, Working Paper, 04.09.2019 tarihinde https: / www.econstor.eu/ bitstream/10419/144869/1/864784821.pdf adresinden alınd1.

Short, S., Sharman, E. ve Speedy, S. (1993). Sociology for nurses: an Australian introduction. South Melbourne: Macmillan.

Singh, B. ve Kiran, U. V. (2015). Impact of educational status on social well being of elderly, International Journal of Research, 2(1), 350-356.

Sudnow, D. (1967). Passing on: the social organisation of dying. Englewood Cliffs, NJ: Prentice Hall.

Verbrugge, L. M. (1985). Gender and health: an update on hypot- 
heses and evidence, Journal of Health and Social Behavior, 26(3), 156-82.

Waghorn, M., Young, H. ve Davies, A. (2011). Opinions of patients with cancer on the relative importance of place of death in the context of a 'good death', Supportive and Palliative Care, 1(3), 310-324.

Walter, T. (2008). The sociology of death. Sociology Compass, 2(1), 317-336.

Warner, W. L. (1959). The living and the dead: a study of the symbolic life of Americans. New Haven, CT: Yale University Press.

Weber, M. (2011). Protestan ahlakı ve kapitalizmin ruhu. Bilgesu Yayincilik.

Worden, J. W. (1991).Grief counseling and grief therapy: a handbook for the mental health practitioner (2nd ed.). New York: Springer.

WHO. (2014). Global atlas of palliative care at the end of life. 14.06.2019 tarihinde https: / / www.who.int/nmh/Global_Atlas_of_Palliative_Care.pdf adresinden alındı.

WHO. (2018). Palliative care, fact sheet Feb 2018, 22 May1s 2019 tarihinde http://www.who.int/mediacentre/factsheets / fs402/en/ adresinden alındı.

$\mathrm{Wu}, \mathrm{Z}$. ve Hart, R. (2002), The effect of marital and nonmarital union transition on health, Journal of marriage and the Family, 64, 420-432.

Zhang, Y. ve Lu, J. H. (2017). Suffering or serene: an empirical study on determinants affecting the dying status of Chinese elderlies, Popul Dev, 2:009. 